\title{
EFEKTIFITAS PIJAT REFLEKSI KAKI TERHADAP PENURUNAN TEKANAN DARAH LANSIA HIPERTENSI \\ DI PSTW BUDI LUHUR YOGYAKARTA
}

\author{
$\underline{\text { Rahmita Nuril Amalia }}{ }^{1}$ \\ Staff Dosen Akademi Keperawatan "YKY" Yogyakarta" \\ Email: rahmitanurilamalia@gmail.com, Hp: 081328805002
}

\begin{abstract}
ABSTRAK
Hipertensi yang pada lansia penting untuk menjadi perhatian karena patofisiologi dan penatalaksanaannya. Hipertensi yang tidak segera ditangani dapat menimbulkan pecahnya pembuluh darah di otak, gagal ginjal, kebutaan dan gangguan kognitif. Penatalaksanaan hipertensi dapat berupa terapi farmakologis dan terapi nonfarmakologis. Salah satu terapi non farmakologis yang dapat digunakan sebagai terapi pendamping terapi farmakologis adalah pijat refleksi kaki untuk menurunkan tekanan darah pada lansia dengan hipertensi. Tujuan dari penelitian ini adalah untuk mengidentifikasi efektifitas pijat refleksi kaki terhadap penurunan tekanan darah lansia dengan hipertensi di PSTW Budi Luhur Yogyakarta.

Design penelitian adalah quasi experiment pre-post test one group. Teknik pengambilan sampel dengan simple random sampling didapatkan 39 responden untuk kelompok intervensi. Pada kelompok intervensi, diberikan terapi pijat refleksi kaki setiap 3 hari sekali selama 8 kali.Tekanan darah lansia diukur setiap sebelum dan 10 menit setelah dilakukan pijat refleksi kaki. Selanjutnya, data dianalisis dengan menggunakan Repeated Measured Anova.

Hasil penelitian membuktikan bahwa penerapan pijat refleksi kaki efektif menurunkan tekanan darah lansia dengan hipertensi $\mathrm{p}<0,01$. Terdapat pengaruh yang bermakna dari penerapan pijat refleksi kaki terhadap penurunan tekanan darah lansia hipertensi.

Penerapan pijat refleksi kaki secara signifikan efektif menurunkan tekanan darah lansia dengan hipertensi. Pijat refleksi kaki direkomendasikan sebagai pertimbangan intervensi keperawatan dalam merawat lansia dengan masalah hipertensi sehingga pasien dapat mencegah komplikasi.
\end{abstract}

Kata kunci : pijat refleksi kaki, hipertensi, lansia. 


\section{PENDAHULUAN}

Komposisi penduduk di dunia saat ini menunjukkan kecenderungan penduduk usia tua. Meningkatnya umur harapan hidup (UHH) dan meningkatnya jumlah lansia saat ini merupakan salah satu dampak dari kemajuan teknologi (Friedman, Bowden, \& Jones. 2008). UHH penduduk dunia secara global pada tahun 2012 adalah 68,1 tahun untuk pria dan 72,7 tahun untuk wanita (World Health Organization [WHO], 2014). Peningkatan UHH juga dialami Indonesia, ditandai dengan UHH 64,5 tahun (tahun 2000), meningkat menjadi 69,43 tahun (tahun 2010), dan 69,65 tahun (tahun 2011) (Kemkes, 2014; WHO, 2014). Menurut Dinas Kesehatan Provinsi Daerah Istimewa Yogyakarta (DIY) (2013), DIY merupakan salah satu kota yang memiliki UHH tertinggi di Indonesia, yaitu usia 68,3 (tahun 2005), usia 69,1 (tahun 2007), 74,1 (tahun 2008), 73,27 (tahun 2011). Meningkatnya jumlah UHH juga berdampak pada bertambahnya jumlah lansia di dunia.

Lansia atau penduduk berusia diatas 60 tahun di dunia diprediksi akan mencapai angka lebih dari satu miliar pada tahun 2020 (Ayranci \& Ozdag, 2006). Jumlah lansia di Amerika juga akan meningkat hingga $24 \%$ pada tahun 2050 (Friedman, Bowden, \& Jones, 2008). Pertumbuhan penduduk lansia di Indonesia mengalami pertumbuhan terbesar di Asia sejak tahun 1990 hingga tahun 2050. Pada tahun 2000 jumlah presentase lansia adalah 7,18\% dari seluruh populasi, meningkat pada tahun 2010 dengan presentase jumlah lansia sebanyak $7,56 \%$, dan menjadi $7,58 \%$ pada tahun 2011 (Kemenkes, 2014).

Peningkatan jumlah lansia di Indonesia perlu mendapat perhatian mengingat agregat lansia termasuk kelompok/ populasi beresiko (population at risk) (Martono, 2011). Populasi beresiko merupakan kelompok yang mempunyai karakteristik tertentu yang dapat menimbulkan masalah kesehatan. Lansia sebagai populasi beresiko mempunyai karakteristik biologis dan usia, sosial, ekonomi, gaya hidup, dan kejadian hidup (Stanhope \& Knollmueller, 2010). Faktor biologis yang terjadi seiring akibat proses menua atau bertambahnya usia berdampak pada perubahan fungsi organ diantaranya jantung terjadi penebalan pada miokardial dan pembuluh darah terjadi kekakuan.

Peningkatan masalah kesehatan pada lansia terjadi karena lansia mempunyai tingkat probabilitas yang tinggi terhadap penyakit daripada kelompok lain, sehingga lansia termasuk juga dalam kelompok rentan (vulnerable population) (Stanhope \& Knollmueller, 2010). Vulnerable population adalah kelompok yang mempunyai karakteristik lebih memungkinkan menimbulkan berkembangnya masalah kesehatan, lebih sulit mengakses pelayanan kesehatan untuk mengatasi masalah kesehatan, kemungkinan besar penghasilannya kurang atau masa hidupnya lebih singkat akibat kondisi kesehatan (Maurer \& Smith, 2005).

Lansia sebagai kelompok beresiko (population at risk) dan kelompok rentan (vulnerable population) yang berjumlah banyak dan meningkat dari tahun ketahun tentu akan menimbulkan berbagai masalah. Penyakit pada sistem kardiovaskuler merupakan salah satu penyebab kematian pada lansia selain penyakit kanker (Anderson \& McFarlane, 2011). Secara global penyakit kardiovaskuler menyebabkan 17 juta kematian pertahun. Dari jumlah tersebut 9,4 juta diantaranya disebabkan oleh komplikasi hipertensi (WHO, 2013).

Jumlah lansia yang mengalami hipertensi di Indonesia yaitu 83 per 100 anggota rumah tangga (Tantriyani \& Harmilah, 2012). Hipertensi yang dialami lansia di Indonesia merupakan yang tertinggi diantara penyakit lainnya yang melakukan rawat inap yaitu, sebanyak 19874 dan meninggal sebanyak 955, serta kasus baru tahun 2010 yang melakukan rawat jalan sebanyak 80615 (Kemenkes, 2011). Hasil Riskesdas tahun 2010 menunjukkan kasus hipertensi di Provinsi DIY mencapai 35\% diatas rata-rata seluruh Indonesia yang mencapai 31,7\%. (Dinkes DIY, 2013). Distribusi kasus hipertensi menurut umur di seluruh Puskesmas yang terdapat di Kota Yogyakarta pada tahun 2011 menunjukkan lansia ( $\geq 60$ tahun) menempati urutan tertinggi yaitu $44,69 \%$ dari total penduduk yang mengalami hipertensi (Dinkes DIY, 2012).

Hipertensi diakui sebagai penyakit yang beresiko menyebabkan penyakit jantung, stroke, penyakit jantung koroner, penyakit ginjal, dan demensia (National Institute for Health and Care Excellence [NICE], 2011). Hipertensi sering disebut sebagai silent killer, hal ini terjadi karena penyakit tersebut tidak memiliki gejala yang khas yang disadari oleh penderitanya (Ramadhan, 2010). Seseorang yang telah didiagnosa hipertensi maka akan selamanya dalam kondisi hipertensi, jika faktor pencetusnya tidak dikendalikan (Smeltzer, Bare, Hinkle, \& Cheever, 2010). Hipertensi yang tidak segera ditangani juga dapat menyebabkan pecahnya pembuluh darah di otak yang dapat menjadi penyebab stroke, dapat juga menyebabkan gagal ginjal, kebutaan, dan gangguan kognitif (WHO, 2013).

Hipertensi pada lansia lebih penting untuk ditangani karena patogenesis, perjalanan penyakit dan penatalaksanaannya. Pada lansia aspek diagnosis hipertensi tidak hanya pada hipertensi dan komplikasinya, akan tetapi berbagai penyakit penyerta yang juga diderita oleh lansia tersebut juga perlu mendapatkan perhatian karena berhubungan erat dengan penatalaksanaan secara 
keseluruhan (Darmojo, 2009). Miller (2011) menyebutkan gangguan kardiovaskuler yang terjadi akibat perubahan menua antara lain hipertrofi ventrikel sinistra, sel pacemaker berkurang, dan pembuluh darah mengalami kekakuan, vena menjadi lebih tebal, kehilangan elastisitas, dan lebih berdilatasi, gangguan barorefleks, perubahan mekanisme konduksi jantung, peningkatan tahanan perifer diperkuat juga oleh adanya faktor resiko yakni obesitas, merokok, diet tinggi lemak, dan kurangnya aktivitas fisik.

Penanganan hipertensi dapat dilakukan secara farmakologis atau dengan obat anti hipertensi dan non farmakologis yaitu dengan memodifikasi gaya hidup (Darmojo, 2009). Penanganan secara farmakologis perlu memperhatikan efek samping yang justru dapat memperberat kondisi kesehatan lansia (Darmojo, 2009). Penanganan secara nonfarmakologis menurut beberapa penelitian telah membuktikan bahwa pengobatan non farmakologi merupakan intervensi wajib yang harus dilakukan pada setiap pengobatan hipertensi (Smeltzer, Bare, Hinkle, \& Cheever, 2010). Kowalski (2010) mengungkapkan bahwa untuk menekan angka kejadian hipertensi dapat dilakukan melalui perubahan gaya hidup, seperti penurunan berat badan, melakukan aktivitas fisik, penurunan konsumsi alkohol, pola makan kaya buah-buahan, sayuran, dan sereal. Penderita hipertensi yang patuh terhadap terapi nonfarmakologi, ada kemungkinan untuk menurunkan dosis dan jumlah obat antihipertensi secara bertahap (Yogiantoro, 2007).

Berdasarkan telaah literatur, terdapat berbagai terapi nonfarmakologis yang disarankan sebagai terapi pendamping terapi medis disebut juga terapi alternatif dan terapi komplementer. National Center for Complementary and Alternative Medicine (NCCAM) menyebutkan terapi komplementer adalah sekelompok perawatan kesehatan, praktek, dan produk yang saat ini tidak dianggap sebagai bagian dari pengobatan konvensional (Synder \& Lindquist, 2010). Oh, Kim, Kwon, \& Park (2006), menyatakan bahwa Complementary and Alternative Medicine (CAM) diperlukan dalam intervensi keperawatan untuk membantu meningkatkan status kesehatan seseorang.

Salah satu bentuk terapi CAM adalah massage therapy. Di dalam massage therapy ini terdapat perlakuan yang salah satunya perlakuan terhadap titik-titik sentra refleks di kaki dan hal ini disebut reflexology (Jones, 2012). Reflexology merupakan salah satu massage therapy yang dapat menyembuhkan hampir semua penyakit, serta merupakan terapi yang aman dan tanpa efek samping. (Pamungkas, 2010). Reflexology merupakan pemberian energi yang dimasukkan ke dalam tubuh melalui pemijatan untuk memperlancar peredaran darah, melenturkan otototot, meningkatkan daya tahan tubuh, relaksasi, meningkatkan kekuatan pikiran dan tubuh, menstabilkan emosi, meningkatkan kualitas tidur, restrukturisasi tulang, otot, dan organ, menyembuhkan cedera baru dan lama, meningkatkan konsentrasi dan ingatan, meningkatkan rasa percaya diri dan harmoni (Jones, Thompson, Irvine, \& Leslie, 2011).

Pada dasarnya reflexology adalah metode untuk memperlancar kembali aliran darah. Adanya pijatan-pijatan terhadap titik sentrarefleks diharapkan terputusnya aliran darah, penyempitan, penyumbatan pada pembuluh darah menjadi normal kembali. Pemijatan/penekanan pada titik-titik sentrarefleks jantung dan hypertension point akan merangsang impuls syaraf bekerja pada sistem syaraf autonomik cabang dari parasimpatik. Pemijatan/penekanan dengan irama yang teratur pada kaki akan merefleksi pada organ-organ yang bersangkutan, menstimulasi syaraf tepi melalui alur-alur persyarafan menuju sistem syaraf pusat dan sistem syaraf belakang sehingga terjadi efek relaksasi dan tubuh dalam keadaan homeostasis. Keadaan homeostasis pada tubuh yang mengenai jantung dan pembuluh darah dapat mengembalikan fungsi dan mampu mengembalikan tekanan darah pada ambang normal (Jones, 2012).

Penelitian yang dilakukan oleh Mohammadpour, Dehnoalian, Mojtabavi (2013) menunjukkan efek positif dari reflexology untuk mengurangi tekanan darah pada pasien stroke secara signifikan setelah kelompok eksperimen menerima foot reflexology selama 30 menit. Hal ini sejalan dengan penelitian Nugroho, Asrin, \& Sarwono (2012) yang menunjukkan bahwa foot reflexology lebih efektif menurunkan tekanan darah dibandingkan hipnoterapi. Park \& Cho (2012) membuktikan bahwa foot reflexology adalah intervensi keperawatan yang efektif untuk menurunkan tekanan sistolik dan trigliserida dan untuk meningkatkan kepuasan hidup tetapi tidak menurunkan kolesterol darah.

Penerapan foot reflexology dalam keperawatan dapat digunakan untuk membantu proses pemulihan pada klien hipertensi, tidak hanya pada klien yang menjalani perawatan di tempat pelayanan kesehatan seperti di Puskesmas atau rumah sakit, tetapi juga dapat dilakukan di rumah maupun di panti. Panti Sosial Tresna Wredha (PSTW) Budi Luhur Yogyakarta merupakan salah panti sosial terbesar di DIY yang menampung para lansia untuk mendapatkan perawatan dalam pemenuhan kebutuhan aktivitas sehari-hari baik secara bio-psiko-sosial dan spiritual. PSTW Yogyakarta Unit Budi Luhur dihuni 88 lansia.

Lansia yang memiliki masalah hipertensi di PSTW Budi Luhur Yogyakarta telah ditangani dengan upaya farmakologis dan nonfarmakologis. Intervensi farmakologis yang telah dilakukan adalah pemberian obat anti hipertensi, analgetik, dan vitamin-vitamin, sedangkan intervensi 
nonfarmakologis yang telah dilakukan adalah senam lansia, dan diit rendah garam. Berdasarkan studi pendahuluan dengan wawancara kepada petugas panti dan beberapa lansia yang menderita hipertensi, didapatkan bahwa lansia sering lupa dalam mengkonsumsi obat anti hipertensi, lansia juga jarang mengikuti senam dengan alasan enggan meninggalkan kamar, serta lansia juga tidak menyukai diit rendah garam yang disediakan oleh petugas panti karena rasanya yang hambar. Upaya penanggulangan hipertensi dengan terapi komplementer khusunya terapi pijat refleksi kaki pada lansia di PSTW Budi Luhur Yogyakarta belum pernah dilakukan.

Dengan demikian, menjadi penting bagi peneliti untuk melakukan penelitian mengenai pada lansia dengan hipertensi di PSTW Budi Luhur Yogyakarta.

\section{METODE PENELITIAN}

Penelitian ini merupakan penelitian quasi eksperimen. Penelitian ini dimulai dengan melakukan pretest pengukuran tekanan darah, kemudian memberikan intervensi pijat refleksi kaki. Intervensi pijat refleksi kaki dilakukan selama 30 menit, setiap 3 hari sekali selama 4 minggu. Pada kelompok intervensi peneliti melakukan pretest sebelum dilakukan pijat refleksi kaki dan melakukan postest setelah 10 menit intervensi selesai. Hal ini selalu dilakukan selama 8 kali intervensi. Selanjutnya tekanan darah lansia dianalisis perbedaannya antara sebelum dan setelah dilakukan intervensi.

\section{HASIL PENELITIAN}

Distribusi frekuensi berdasarkan karakteristik subjek penelitian $(\mathrm{n}=148)$

Tabel 1.1 Distribusi frekuensi berdasarkan karakteristik partisipan di PSTW Yogyakarta tahun $2016(n=39)$

\begin{tabular}{lcc}
\hline Karakteristik partisipan & $\begin{array}{c}\text { Kelompok } \\
\text { intervensi }\end{array}$ & \\
\cline { 2 - 3 } & $\mathbf{f}$ & $\mathbf{\%}$ \\
\hline Usia & 15 & 38,5 \\
$50-69$ tahun & 18 & 46,2 \\
$70-79$ tahun & 6 & 15,4 \\
$80-90$ tahun & & \\
Gender & 19 & 48,7 \\
Laki-laki & 20 & 51,3 \\
Perempuan & & \\
Riwayat keluarga dengan & & \\
hipertensi & 29 & 74,4 \\
Ada & 10 & 25,6 \\
Tidak & & \\
IMT & 8 & 20,5 \\
Kurus & 24 & 61,5 \\
Berat badan normal & 6 & 15,4 \\
Berat badan berlebih & 1 & 2,6 \\
Obesitas kelas 1 & & \\
Diabetes Mellitus & & \\
\hline
\end{tabular}

$\leq 200 \mathrm{mg} / \mathrm{dl}$

35

$\geq 200 \mathrm{mg} / \mathrm{dl}$

89,7

Diet

Konsumsi garam

Tidak suka mengkonsumsi

makanan asin

Konsumsi kafein

$\leq 1$ gelas per hari

Merokok

Merokok

Konsumsi

hipertensi

obat anti

Ya

Jenis Obat Hipertensi

Captopril

Lama

hipertensi

menderita

100

1 tahun

2 tahun

3 tahun

4 tahun

5 tahun

6 tahun

7 tahun

8 tahun

9 tahun

Tabel 1.1 menunjukkan bahwa kelompok usia partisipan terbanyak pada kelompok intervensi dan kelompok kontrol adalah berada pada usia 70-79 tahun. Gender terbanyak adalah perempuan. Riwayat keturunan keluarga dengan hipertensi terbanyak adalah memilki riwayat keturunan hipertensi. Status obesitas lansia berdasarkan IMT terbanyak adalah lansia dengan berat badan normal. Status diabetes mellitus berdasarkan perhitungan gula darah sewaktu pada lansia, terbanyak adalah memiliki kadar gula darah normal. Diet yang dijalani lansia berhubungan dengan konsumsi garam terbanyak adalah lansia tidak suka mengkonsumsi makanan asin. Diet yang dijalani lansia berhubungan dengan konsumsi kopi terbanyak adalah mengkonsumsi kopi $\leq 1$ gelas/hari. Kebiasaan merokok lansia terbanyak adalah lansia tidak memiliki kebiasaan merokok. Konsumsi obat anti hipertensi terbanyak adalah captopril yang diresepkan kepada seluruh lansia dengan masalah hipertensi. Lama menderita hipertensi terbanyak adalah 1 tahun.

Tabel 1.2 Mean dan SD tekanan darah sistolik dan diastolik pada pengukuran ke-1sampai dengan pengukuran ke-16 $(\mathrm{n}=39)$

\begin{tabular}{lllll}
\hline Waktu & \multicolumn{2}{l}{ Sistolik } & \multicolumn{3}{c}{ Diastolik } \\
\cline { 2 - 5 } Pengukuran & Mean & SD & Mean & SD \\
\hline T0 & 178,46 & 15,81 & 98,21 & 8,54 \\
T1 & 171,03 & 18,75 & 96,41 & 6,68 \\
T2 & 171,03 & 17,28 & 96,15 & 12,48 \\
T3 & 164,36 & 17,74 & 89,74 & 12,24 \\
T4 & 160,77 & 21,07 & 90,00 & 8,27
\end{tabular}




\begin{tabular}{lllll} 
T5 & 155,90 & 18,31 & 85,38 & 11,20 \\
T6 & 156,92 & 20,41 & 85,90 & 6,77 \\
T7 & 152,31 & 17,23 & 84,10 & 5,94 \\
T8 & 153,59 & 17,24 & 85,64 & 10,20 \\
T9 & 148,21 & 14,84 & 82,82 & 8,87 \\
T10 & 146,92 & 16,40 & 86,15 & 9,06 \\
T11 & 141,28 & 13,41 & 79,74 & 8,10 \\
T12 & 138,21 & 10,22 & 80,77 & 9,28 \\
T13 & 137,44 & 9,09 & 80,26 & 9,02 \\
T14 & 135,38 & 7,55 & 79,49 & 8,87 \\
T15 & 134,62 & 7,55 & 77,95 & 7,67 \\
\hline
\end{tabular}

Berdasarkan tabel 1.2 dapat digambarkan bahwa terdapat penurunan tekanan darah sistolik dan diastolik sejak pengukuran awal (T0) sampai dengan pengukuran akhir (T15) pada setiap pelaksanaan intervensi pijat refleksi pada kelompok intervensi.

Tabel 1.3 Mean dan SD tekanan darah sistolik dan diastolik pretest sebelum intervensi pijat refleksi (n

\begin{tabular}{lllll} 
=39) & & & \\
\hline Waktu & Sistolik & \multicolumn{3}{c}{ Diastolik } \\
\cline { 2 - 5 } Pengukuran & Mean & SD & Mean & SD \\
\hline T0 & 178,46 & 15.81 & 98,21 & 8,54 \\
T2 & 171,03 & 17,28 & 96,15 & 12,48 \\
T4 & 160,77 & 21,07 & 90 & 8,27 \\
T6 & 156,92 & 20,41 & 85,9 & 6,77 \\
T8 & 153,59 & 17,24 & 85,64 & 10,20 \\
T10 & 146,92 & 16,40 & 86,15 & 9,06 \\
T12 & 138,21 & 10,22 & 80,77 & 9,28 \\
T14 & 135,38 & 7,55 & 79,49 & 8,87 \\
\hline
\end{tabular}

Berdasarkan tabel 1.3 diketahui bahwa tekanan darah sistolik dan diastolik pretest mengalami penurunan pada setiap pelaksanaan intervensi pijat refleksi pada kelompok intervensi.

Tabel 1.4 Mean dan SD tekanan darah sistolik dan diastolik posttest setelah intervensi pijat refleksi kaki $(\mathrm{n}=39)$

\begin{tabular}{lllll}
\hline Waktu & \multicolumn{3}{l}{ Sistolik } & \multicolumn{2}{l}{ Diastolik } \\
\cline { 2 - 5 } Pengukuran & Mean & SD & Mean & SD \\
\hline T1 & 171,03 & 18,75 & 96,41 & 6,68 \\
T3 & 164,36 & 17,74 & 89,74 & 12,24 \\
T5 & 155,9 & 18,31 & 85,38 & 11,20 \\
T7 & 152,31 & 17,23 & 84,1 & 5,94 \\
T9 & 148,21 & 14,84 & 82,82 & 8,87 \\
T11 & 141,28 & 13,41 & 79,74 & 8,10 \\
T13 & 137,44 & 9,09 & 80,26 & 9,02 \\
T15 & 134,62 & 7,55 & 77,95 & 7,67 \\
\hline
\end{tabular}

Berdasarkan tabel 1.4 diketahui bahwa tekanan darah sistolik dan diastolik posttest mengalami penurunan pada setiap pelaksanaan intervensi pijat refleksi kaki pada kelompok intervensi.

Tabel 1.5 Perbedaan tekanan darah sistolik dan diastolik pretest dan posttest harian $(\mathrm{n}=39)$

\begin{tabular}{lllllll}
\hline Variabel & Type & III & Df & Mean & F & $P$ \\
\hline
\end{tabular}

\begin{tabular}{|c|c|c|c|c|c|}
\hline & $\begin{array}{l}\text { Sum of } \\
\text { Aquares }\end{array}$ & & Square & & \\
\hline \multicolumn{6}{|l|}{ Sistolik } \\
\hline T0-T15 & 109926,7 & 5,6 & 19358,5 & 72,6 & 0,0 \\
\hline & 6 & 7 & 9 & & 0 \\
\hline Pretest: & 61545,83 & 4,4 & 13975,3 & 77,7 & 0,0 \\
\hline $\begin{array}{l}\text { T0, T2, } \\
\text { T4,T6, } \\
\text { T8, T10, } \\
\text { T12, } \\
\text { T14 }\end{array}$ & & 0 & 4 & 2 & 0 \\
\hline Posttest: & 45194,87 & 3,9 & 11405,9 & 65,4 & 0,0 \\
\hline $\begin{array}{l}\mathrm{T} 1, \mathrm{~T} 3, \\
\mathrm{~T} 5, \mathrm{~T} 7, \\
\mathrm{~T} 9, \mathrm{~T} \\
11, \mathrm{~T} 13, \\
\mathrm{~T} 15\end{array}$ & & 6 & 6 & 1 & 0 \\
\hline \multicolumn{6}{|l|}{ Diastoli } \\
\hline & 23828,04 & $\begin{array}{l}5,6 \\
0\end{array}$ & 4252,67 & $\begin{array}{l}42,7 \\
8\end{array}$ & $\begin{array}{l}0,0 \\
0\end{array}$ \\
\hline Pretest: & 12184,29 & 4,2 & 2843,23 & 43,4 & 0,0 \\
\hline $\begin{array}{l}\text { T0, T2, } \\
\text { T4,T6, } \\
\text { T8, T10, } \\
\text { T12, } \\
\text { T14 }\end{array}$ & & 8 & & 6 & 0 \\
\hline Posttest: & 10008,97 & 4,1 & 2411,20 & 38,4 & 0,0 \\
\hline $\begin{array}{l}\text { T1, T3, } \\
\text { T5, T 7, } \\
\text { T 9, T } \\
11, \mathrm{~T} 13, \\
\text { T15 }\end{array}$ & & 5 & & 5 & 0 \\
\hline
\end{tabular}

Berdasarkan hasil uji Repeated Measures Annova diketahui bahwa tekanan darah sistolik (T0-T15) selama intervensi baik pretest maupun postest menunjukkan bahwa terdapat perbedaan nilai sistolik T0 - T15 dengan nilai $\mathrm{F}$ 72,64, p $<0,01$. Tekanan darah sistolik pretest mengalami perbedaan pada setiap intervensi pijat refleksi dengan nilai $\mathrm{F} 77,72, \mathrm{p}<0,01$. Tekanan darah sistolik posttest mengalami perbedaan pada setiap intervensi pijat refleksi dengan nilai $\mathrm{F} 65,41$, $\mathrm{p}<$ 0,01 .

Tekanan diastolik (T0-T15) selama intervensi baik pretest maupun postest menunjukkan bahwa terdapat perbedaan nilai diastolik T0 - T15 dengan nilai $F$ 42,78, $p<0,01$. Tekanan darah diastolik pretest mengalami perbedaan pada setiap intervensi pijat refleksi dengan nilai $\mathrm{F}$ 43,46, $\mathrm{p}<0,01$. Tekanan darah sistolik posttest mengalami perbedaan pada setiap intervensi pijat refleksi dengan nilai $\mathrm{F} 38,45, \mathrm{p}<0,01$.

\section{PEMBAHASAN}

Pada penelitian ini, karakteristik partisipan berdasarkan usia lansia yang mengalami hipertensi terbanyak berada pada usia 70-79 tahun, hal ini sesuai dengan penelitian Rahajeng (2009), yang menyebutkan bahwa sejalan dengan bertambahnya usia dan usia kelompok $\geq 70$ tahun lebih beresiko 11,53 kali dibandingkan usia 18-24 tahun. Berdasarkan jenis kelamin lansia yang mengalami 
hipertensi terbanyak adalah perempuan, hal ini sejalan dengan penelitian Wong, et al (2010), Eugene \& Bourne (2013), dan Li, et al (2015), yang menyebutkan bahwa perempuan terutama pada daerah urban lebih beresiko sebanyak 52,6\% menderita hipertensi dibandingkan dengan lakilaki.

Berdasarkan riwayat keturunan hipertensi pada keluarga, lansia yang mengalami hipertensi terbanyak memiliki keturunan hipertensi pada keluarga, hal ini sejalan dengan penelitian Anggraini (2009) yang menyebutkan bahwa 70$80 \%$ kasus hipertensi esensial dengan riwayat hipertensi dalam keluarga. Status obesitas lansia terbanyak adalah lansia yang memiliki IMT normal, hal ini sesuai dengan penelitian yang dilakukan oleh Rahajeng (2009), Wong et al (2010), dan Eugene \& Bourne (2013), yang melaporkan bahwa IMT penderita hipertensi dalam rentang normal sebanyak $31 \%$.

Status diabetes mellitus berdasarkan hasil pengukuran kadar gula darah sewaktu menunjukkan bahwa lansia terbanyak memiliki kadar gula darah normal $(<200 \mathrm{mg} / \mathrm{dl})$, hal ini sesuai dengan Rahajeng (2009) yang menyebutkan bahwa $98 \%$ pasien hipertensi tidak memiliki riwayat penyakit diabetes mellitus. Status diet lansia berdasarkan konsumsi garam menunjukkan bahwa seluruh lansia tidak suka mengkonsumsi makanan asin, hal ini kurang sesuai dengan Rahajeng (2009) yang menyebutkan bahwa $65,6 \%$ penderita hipertensi mengkonsumsi garam sebanyak < 6 gram/hari. Konsumsi kafein menunjukkan bahwa seluruh lansia mengkonsumsi kafein $\leq 1$ gelas/hari, hal ini sesuai dengan penelitian Eugene \& Bourne (2013) yang menyebutkan bahwa lansia yang mengkonsumsi kopi $\leq 1$ gelas/hari juga beresiko terkena hipertensi sebanyak $31 \%$.

Berdasarkan kebiasaan merokok diketahui bahwa seluruh lansia tidak mempunyai kebiasaan merokok. Hal ini sesuai dengan penelitian yang dilakukan oleh Wong et al (2010) yang melaporkan bahwa penderita hipertensi terbanyak tidak pernah merokok yaitu sebesar 95\%. Hayes (2010) menyatakan bahwa merokok merupakan salah satu faktor resiko terjadinya hipertensi, namun pada orang yang tidak merokok juga mempunyai peluang untuk menderita hipertensi akibat pola makan atau gaya hidupnya.

Berdasarkan konsumsi obat antihipertensi diketahui bahwa seluruh lansia mengkonsumsi obat anti hipertensi dengan jenis captopril. Hal ini sesuai dengan penelitian Ikawati (2007), yang menyebutkan bahwa sebagian besar lansia yang didiagnosis hipertensi pada akhirnya akan menjalani terapi menggunakan obat anti hipertensi. Obat anti hipertensi yang sering diresepkan pada hipertensi yang dialami oleh lansia adalah golongan obat $A C E$ Inhibitor dengan jenis captopril sebanyak
55\%. Lama menderita hipertensi partisipan terbanyak adalah 1 tahun. Hal ini sesuai dengan penelitian yang dilakukan oleh Akhter (2010), yang menyebutkan bahwa lama pasien menderita hipertensi 1 tahun adalah sebesar 67,3\%.

Uji statistik pada penelitian ini terlebih dahulu dilakukan uji normalitas data. Menurut uji normalitas, sebaran data berdistribusidi tidak normal, sehingga uji statistik yang digunakan selanjutnya adalah Uji Wilcoxon untuk menganalisis tekanan darah pretest dan posttest. Uji Repeated Measured Anova digunakan untuk melihat perbedaan penurunan tekanan darah setiap dilakukan intervensi (Dahlan, 2009).

Berdasarkan uji tersebut, menunjukkan bahwa terapi pijat refleksi yang dikombinasikan dengan obat antihipertensi memberikan pengaruh terhadap penurunan tekanan darah lansia dengan masalah hipertensi. Hal ini ditunjukkan dalam tabel 4.2 dengan adanya perbedaan rerata tekanan darah sistolik sebelum dan setelah diberikan intervensi pijat refleksi pada kelompok intervensi $(\mathrm{p}=0,00)$ dan perbedaan rerata tekanan darah diastolik sebelum dan setelah diberikan intervensi pijat refleksi pada kelompok intervensi $(p=0,00)$. Hal ini sesuai dengan penelitian Mohammadpour, Dehnoalian, \& Mojtabavi (2013), yang melakukan penelitian untuk melihat pengaruh pijat refleksi, sebagai teknik non farmakologis terhadap tekanan darah sistolik dan diastolik pada pasien dengan stroke. Penelitian ini dilakukan pada 68 pasien stroke, kemudian dipisahkan menjadi kelompok eksperimen dan kelompok kontrol. Pasien pada kelompok eksperimen menerima pijat refleksi selama 30 menit. Data di catat melalui data demografi dan tekanan darah. Data dianalisis menggunakan t-test dan ANNOVA.

Pada awal penelitian tidak ditemukan perbedaan yang signifikan tekanan darah sistolik dan diastolik partisipan. Tekanan darah berkurang secara signifikan setelah menerima pijat refleksi ( $\mathrm{p}$ $<0,05$ ). Tekanan darah sistolik rata-rata berkurang pada 10 dan 30 menit setelah mendapat pijat refleksi dan tekanan darah diastolik juga berkurang pada setiap pengukuran setelah menerima pijat refleksi $(\mathrm{p}<0,05)$. Penelitian Mohammadpour, Dehnoalian, \& Mojtabavi (2013), menunjukkan efek positif dari pijat refleksi untuk mengurangi tekanan darah pada pasien stroke.

Nugroho, Asrin, \& Sarwono (2012), juga melakukan penelitian untuk melihat perbedaan dan efektifitas penggunaan pijat refleksi dan hipnoterapi dalam menurunkan tekanan darah pasien dengan metode kuasi eksperimen. Penelitian ini menggunakan 60 orang sampel yang dibagi menjadi dua kelompok, 30 partisipan dilakukan pijat refleksi dan 30 partisipan dilakukan 
hipnoterapi. Selanjutnya data dianalisis dengan uji Mann Whitney U-test ditemukan Sig. pijat refleksi adalah 0,000 , dan hipnoterapi menunjukkan Sig. 0,001 dengan $p<0,05$ yang berarti terdapat perbedaan yang signifikan antara pijat refleksi dengan hipnoterapi. Dari hasil penelitian tersebut ditemukan bahwa pijat refleksi lebih efektif dalam menurunkan tekanan darah dibandingkan dengan hipnoterapi.

Sedikit berbeda dengan penelitian Park \& Cho (2012), hasil penelitian yang dilakukan oleh peneliti menunjukkan penurunan tekanan darah baik sistolik maupun diastolik. Park \& Cho (2012) melakukan penelitian untuk mengevaluasi efek pijat refleksi pada tekanan darah, kadar lipid serum, dan kepuasan hidup pada pasien hipertensi esensial. Desain penelitian yang digunakan adalah nonequivalent control group pretest-posttest design. Sampel penelitian adalah 34 partisipan yang dibagi menjadi dua, 18 partisipan pada kelompok eksperimen dan 16 partisipan pada kelompok kontrol. Pada kelompok eksperimen, pijat refleksi diberikan dua kali dalam seminggu selama 6 minggu dan pijat refleksi secara mandiri dilakukan dua kali seminggu selama 4 minggu.

Hasilnya, terdapat penurunan signifikan pada tekanan darah sistolik tetapi tidak ada penurunan yang signifikan pada tekanan diastolik pada kelompok eksperimen dibandingkan dengan kelompok kontrol. Tingkat kolesterol dalam kelompok eksperimen tidak signifikan mengalami penurunan setelah dilakukan pijat refleksi. Namun tingkat trigliserida pada kelompok eksperimen menurun secara signifikan dibandingkan dengan kelompok kontrol. Kepuasan hidup pada kelompok eksperimen secara signifikan membaik setelah dilakukan pijat refleksi.

Penelitian Park \& Cho (2012), membuktikan bahwa pijat refleksi adalah intervensi keperawatan yang efektif untuk menurunkan tekanan sistolik, dan trigliserida tetapi tidak untuk kolesterol darah dan untuk meningkatkan kepuasan hidup.

Hipertensi pada populasi lansia didefinisikan sebagai tekanan darah sistolik $140 \mathrm{mmHg}$ dan tekanan darah diastolik $90 \mathrm{mmHg}$ (JNC VII, 2003). Hipertensi yang terjadi pada lansia selain merupakan akibat dari proses alamiah penuaan juga disebabkan oleh beberapa faktor resiko. Faktor yang mempengaruhi prognosis hipertensi menurut JNC-VII (2003) dan Hayes (2010) terdiri dari usia, jenis kelamin, riwayat keluarga, obesitas, diabetes mellitus, stress, diet, dan merokok.

Secara anatomis sistem kardiovaskuler lansia mengalami perubahan diantaranya hipertofi ventrikel sinistra, hipertrofi tunika media, penurunan elastisitas arteri, penebalan intima, dan perubahan mekanisme barorefleks, sehingga menyebabkan sistem elektrofisiologi yang terjadi dalam jantung menjadi berkurang (Miller, 2011). Berkurangnya sistem elektrofisiologi disebabkan juga oleh peningkatan jumlah lemak dalam miokardium, kolagen, dan serabut elastis. Hal ini mengakibatkan terbatasnya lumen pembuluh darah yang dapat menyebabkan endotelium tidak mampu melakukan vasodilatasi dan meningkatkan tekanan perifer, gangguan baroreseptor, serta aliran darah ke organ berkurang, sehingga berdampak pada meningkatnya tekanan darah atau hipertensi.

Upaya penatalaksanaan hipertensi pada lansia meliputi upaya farmakologis dan non farmakologis. Upaya farmakologis untuk lansia dengan masalah hipertensi perlu mempertimbangkan adanya gangguan absorbsi dalam alat pencernaan, interaksi obat, efek samping obat, dan gangguan akumulasi obat terutama obat-obat yang ekskresinya melalui ginjal. Penderita hipertensi yang patuh terhadap terapi non farmakologis, ada kemungkinan untuk menurunkan dosis dan jumlah obat antihipertensi secara bertahap (Yogiantoro, 2007). Pendekatan non farmakologis termasuk menurunkan berat badan, pembatasan alkohol, natrium dan tembakau, latihan fisik dan relaksasi merupakan intervensi wajib yang harus dilakukan dalam setiap terapi hipertensi (Smeltzer, Bare, Hinkle, \& Cheever, 2010).

Salah satu terapi nonfarmakologis yang disarankan sebagai terapi pendamping terapi medis disebut juga terapi komplementer. Terapi komplementer bertujuan untuk memperbaiki fungsi dari sistem-sistem tubuh terutama sistem kekebalan dan pertahanan tubuh, sehingga tubuh dapat menyembuhkan dirinya sendiri (self healing). Terapi komplementer ini dilakukan sebagai pendukung terhadap pengobatan medis secara terintegrasi sehingga mempengaruhi keharmonisan individu dari aspek biologis, psikologis dan spiritual (Smith et al., 2004). Kondisi ini sesuai dengan prinsip keperawatan dengan memandang manusia sebagai makhluk yang holistik (bio, psiko, sosial dan spiritual). Selain itu, terapi komplementer meningkatkan kesempatan perawat dalam menunjukkan caring pada klien (Synder \& Lindquis, 2010). Oh, Kim, Kwon, \& Park (2006), menyatakan bahwa Complementary and Alternative Medicine (CAM) diperlukan dalam intervensi keperawatan untuk membantu meningkatkan status kesehatan seseorang. Salah satu bentuk terapi CAM adalah massage therapy. Di dalam massage therapy ini terdapat perlakuan yang salah satunya perlakuan terhadap titik-titik sentra refleks di kaki dan hal ini disebut pijat refleksi (Jones, 2012).

Berdasarkan beberapa hasil penelitian, pijat refleksi merupakan salah satu terapi komplementer yang dapat diaplikasikan dalam menurunkan 
tekanan darah pasien hipertensi. Dengan teknik pemijatan/penekanan, pijat refleksi dapat memberikan efek relaksasi pada bagian tubuh yang berkaitan dengan area pemijatan. Relaksasi merupakan tahap pertama dari normalisasi atau pemulihan, pengembangan tubuh pada suatu keadaan yang seimbang (homeostasis), dimana sirkulasi atau aliran darah dan cairan tubuh dapat berlangsung tanpa hambatan dan dapat memasok nutrisi dan oksigen ke sel-sel tubuh, sehingga organ tubuh yang terdiri dari sejumlah sel akan kembali pada keadaan dan fungsi yang normal (Jones, Thompson, Irvine, \& Leslie, 2011).

Reflexology Association of Connecticut (2005) menjelaskan bahwa reflexology bekerja melalui syaraf-syaraf tepi. Tekanan-tekanan yang diberikan pada tangan atau kaki akan menstimulasi sistem syaraf tepi melalui alur-alur persyarafan menuju sistem syaraf pusat dan sistem syaraf belakang, yang akan merangsang penurunan hormon adrenalin sehingga akan menyebabkan terjadinya vasodilatasi pada pembuluh dan menimbulkan relaksasi serta ketenangan tubuh. Pijat refleksi menurut TCM Meridian Theory (Chi atau Khi) dapat membantu membersihkan adanya sekatsekat/blok/benda asing sepanjang saluran dalam tubuh. Hal ini dapat membantu memaksimalkan cara kerja obat anti hipertensi golongan ACE (Angiotensin Converting Enzyme) inhibitor yang bekerja untuk menghambat kerja enzim yang mengubah angiotensin. Angiotensin II merupakan suatu zat aktif yang mengakibatkan vasokontriksi pembuluh darah, sehingga jika angiotensin II dihambat maka pembuluh darah akan mengalami vasodilatasi sehingga tekanan dalam pembuluh darah tidak meningkat (Karch, 2011).

Berdasarkan Uji Repeated Measures Annova dapat disimpulkan bahwa tekanan darah sistolik dan diastolik lansia dengan masalah hipertensi di PSTW Yogyakarta Unit Budi Luhur yang mendapatkan intervensi pijat refleksi mengalami penurunan sejak hari ke-1 intervensi sampai dengan hari ke-8. Hal ini membuktikan bahwa efek penerapan terapi pijat refleksi dapat menurunkan tekanan darah lansia dengan masalah hipertensi.

Dengan demikian terbukti bahwa penggunaan terapi standar obat anti hipertensi akan lebih maksimal dalam menurunkan tekanan darah lansia dengan masalah hipertensi jika dikombinasikan dengan terapi pijat refleksi.

\section{SIMPULAN}

Berdasarkan hasil penelitian terhadap 39 partisipan dan uraian dalam pembahasan, dapat diambil beberapa kesimpulan sebagai berikut:

1. Karakteristik lansia dengan masalah hipertensi di Unit Budi Luhur sebagian besar berusia 70-
79 tahun, gender terbanyak adalah perempuan, lansia dengan masalah hipertensi memilik riwayat keturunan hipertensi, berat badan lansia terbanyak adalah normal, gula darah lansia terbanyak adalah normal, lansia mengkonsumsi garam $<6$ gram/hari, lansia mengkonsumsi kafein $\leq 1$ gelas/hari, lansia tidak memiliki kebiasaan merokok, lansia mengkonsumsi obat anti hipertensi dengan jenis captopril, dan lama menderita hipertensi terbanyak adalah 1 tahun.

2. Ada perbedaan tekanan darah sistolik sebelum dan setelah terapi pijat refleksi

3. Ada perbedaan tekanan darah diastolik sebelum dan setelah terapi pijat refleksi

\section{DAFTAR PUSTAKA}

Akhter, A. (2010). Self Management Among Patient with Hypertension in Bangladesh. A Thesis: Price of Songkla University.

Arthini, W.B., Sawitri, K.A., Nurhesti, O.Y. (2015). Pengaruh terapi warna hijau terhadap tekanan darah sistolik pada lansia di panti sosial tresna werdha wana seraya denpasar. Community of Publishing in Nursing.

Ayranci, U., \& Ozdag, N. (2006). Health of elderly: imprtence of nursing and family medicine care. The Internet Journal of Geriatrics and Gerontology, 1.

Corwin, Elizabeth. J. (2009). Patofisiologi: Buku Saku, alih bahasa Nike Budhi Subekti; editor edisi bahasa Indonesia, Egi Komara Yudha edisi ke-3. Jakarta: EGC

Darmojo, R. Boedhi. (2009). Geriatri (Ilmu Kesehatan Usia Lanjut) edisi ke-4. Jakarta: Balai Penerbit FKUI

Depkes RI. (2007). Pedoman Pengukuran dan Pemeriksaan. Jakarta: Badan Penelitian dan Pengembangan Kesehatan Kementrian Kesehatan RI

Depkes RI. (2013). Masalah Hipertensi di Indonesia.

Depkes RI. (2013). Riset Kesehatan Dasar. Jakarta: Badan Penelitian dan Pengembangan Kesehatan Kementrian Kesehatan RI

Dinas Kesehatan DIY. (2013). Profil Kesehatan Daerah Istimewa Yogyakarta.

Ernst, E. (2009). Systemathic Review: Is reflexology an effective intervention?A systematic review of randomised controlled trials. 
Friedman, M. M., Bowden, V. R., \& Jones, E. G. (2008). Family Nursing Research, Theory, \& Practice. New Jersey: Pearson Education, Inc.

Grispun, D., Coote, T. (2005). Nursing best practice guideline nursing management of hypertension. Registered Nurses Assosiation of Ontario

Hadibroto, Yasmine. (2006). Seluk-Beluk Pengobatan Alternatif dan Komplementer. Jakarta : PT Bhuana Ilmu Populer.

Hayes, M. K. (2010). Influence of age and health behaviours on stroke risk; Lesson from Longitudinal Studies. Journal Compilation The American Geriatrics Society, 6, 12-19

Jones, J. (2012). The Acute (Immediate) Spesific Haemodynamis Effects of Reflexology. Departement of Nursing \& Midwifery Stirling University, Center for Health Science Old Perth Road, Iverness, IV2 3JH.

Jones, J., Thompson, Patricia., Irvine, Katheleen., Leslie, Stephen. J. (2011). Is There a Specific Hemodynamic Effect in Reflexology? A Systematic Review of Randomized Controlled Trials.

JNC VII. (2003). The Seventh Report of The Joint National Committee on Prevention, Detection, Evaluation and Treatment of High Blood Pressure. JAMA

Kementrian Kesehatan RI. (2014). Profil Kesehatan Indonesia Tahun 2013. Jakarta: Kementrian Kesehatan RI.

Kharisna, D., Dewi, W. N., Lestari, W. (2012). Efektifitas Konsumsi Jus Mentimun Terhadap Penurunan Tekanan Darah Pada Pasien Hipertensi. Jurnal Ners Indonesia, 2 (2). Hal 124-131.

Kowalski, E. Robert. (2010). Terapi Hipertensi. Terjemahan: Rani S. Bandung: Qanita

Kozier, Erb, Berman, \& Synder. (2010). Fundamentals of Nursing The Art and Science of Nursing Care. Lippincott: Philadelphia.

Ikawati, Z., Djumiani, S., \& Putu, I, D. (2008). Kajian Keamanan Pemakaian Obat Anti-Hipertensi di Poliklinik Usia Lanjut Instalasi Rawat Jalan RS Dr Sardjito. Majalah Ilmu Kefarmasian. 5 (3). Hal 150-169

Li, Gang., Hu, Huanhuan., Dong, Zhong., Xie, Jin., Zhou, Ying. (2015). Urban and Suburban Differences in Hypertension Trends and Self-Care:
Three Population-Based Cross-Sectional Studies from 2005-2011. Journal PLOS One. Hal 1-11.

Maurer, F. A., \& Smith, C. M. (2005). Community/Public Health Nursing Practice: Health for Families and Populations. Philadelphia: Elsevier Saunders.

Martono, H. (2011). Lanjut Usia dan Dampak Sistemik dalam Siklus Kehidupan. Jakarta: Komisi Nasional Lanjut Usia

Mckenzie, J. F., Pinger, R. R., Kotecki, J. E. (2007). Kesehatan Masyarakat: Suatu Pengantar, edisi 4. Jakarta: EGC.

Miller, C. A. (2011). Nursing Care Of Older Adults: Theory and Practice. Philadelphia: J. B Lippincott Company.

Mohammadpour, Ali., Dehnoalian, Atefeh., Mojtabavi, Javad. (2013). Effect of Foot Reflexology on Blood Pressure in Patients with Stroke [Farsi]. Diakses dari http://web.ebscohost.com pada tanggal 15 Desember 2013.

Mubarak, W. Iqbal. (2007). Ilmu Keperawatan Komunitas Konsep dan Aplikasi. Jakarta: Salemba Medika

Meyer, R. P., Ciolino, J. O’Brien, T. X. (2012). Using a complementary herbal therapy in heart failure. Intergrative Medicine 11 (2) 38-41.

National Institute for Health and Care Excellence (2011) Clinical Guideline 127. Hypertension: clinical management of primary hypertension in adults. Diakses dari http://publications.nice.org.uk/hypertensioncg127

Nkosi, N. G. (2010). Knowledge related to nutrition and hypertension management practice adult in Ga-Rankuwa dat Clinics. Research article, $1,33-39$

Nugroho, I. A., Asrin., Sarwono. (2012). Efektifitas pijat refleksi kaki dan hipnoterapi terhadap penurunan tekanan darah pada pasien hipertensi. Diakses dari http://www.ejournal.stikesmuhgombong.ac.id

Nugroho, Wahyudi. (2008). Keperawatan Gerontik \& Geriatrik. Edisi ke 3. Jakarta: EGC

Oh, K., Kim, K. S., Kwon, S. H., \& Park, J. W. (2006). Research Trend of Complementary and Alternative Medicine. J Korean Acad Nurs. 2006 Aug; 36 (5): 721-731. Korean 
Onkonta, Nkechi Rose. (2012). Does Yoga Therapy Reduce Blood Pressure in Patients With Hypertension?: an integrative review. Journal Holistic Nursing Practice. 2012 May-Jun; 26 (3): 137-41.

Oxenford, R. (2013). Reflexology: A Concise Guide to Foot and Hand Massage for Enhanced Health and Wellbeing. Lorenz Books.

Pamungkas, Refalino. (2009). Jari Refleksi Pijat Refleksi Dengan Jari. Yogyakarta: Lafal Indonesia

Pamungkas, R. (2010). Dahsyatnya Jari Refleksi. Yogyakarta: Pinang Merah

Park HS., Cho GY. (2012). Effects of foot reflexology on essential hypertension patients. Diakses dari http://web.ebscohost.com

Potter, P.A. \& Perry, A.G. (2009). Fundamental Keperawatan Edisi 7 Buku 1. Jakarta: Penerbit Salemba Medika

Rahajeng, E \& Tuminah, S. (2009). Prevalensi Hipertensi dan Determinannya di Indonesia. Jakarta: Pusat Penelitian Biomedis dan Farmasi Badan Penelitian Kesehatan Departemen Kesehatan RI.

Ramadhan, A.J. (2010). Mencermati Berbagai Gangguan pada Darah dan Pembuluh Darah. Yogyakarta: Diva Press.

Reflexology Association of Connecticut. (2005). What Are The Benefits Of Reflexology. Diakses dari http://www.reflexologyst.org/ractfaqs.html

Rohaendi. (2008). Treatment of High Blood Pressure. Jakarta: Gramedia Pustaka Umum

Sari, C. Y. (2015). Penggunaan Buah Mengkudu (Morinda Citrifolia. L) Untuk Menurunkan Tekanan Darah. Jurnal Majority 4 (3) 34-40.

Shen, C., Pang, S. M. C., Kwong, E. W. Y \& Cheng, Z. Q. (2010). The effect of Chinese food therapy on community dwelling Chinese Hypertensive Patiens with Yin-deficiency. Blackwell Publishing Ltd, Journal of Clinical Nursing 19, 1008-1020.

Smeltzer, S. C., Bare, B. G., Hinkle, J. L., \& Cheever, K. H. (2010). Brunner \& Suddarth's textbook of medical surgical nursing (12th ed). Philadelphia: Lippincott Williams \& Wilkins.

Smith, S. F., Duell, D. J., Martin, B. C. (2004). Clinical nursing skills: Basic to advanced skills. New Jersey: Pearson Prentice Hall.
Stanhope, Marcia., Knollmueller, R.N. (2010) Praktik Keperawatan Kesehatan Komunitas, (ed. 2), Jakarta: EGC

Stanley, M., \& Beare, P. G. (2006). Buku Ajar Keperawatan Gerontik. Jakarta: EGC

Stockslager, Jaime. (2008). Asuhan Keperawatan Gerontik, Edisi 2. Jakarta: EGC

Synder, M., Lindquist, R. (2010). Complementary and Alternative Therapies in Nursing (Sixth). New York: Springer Publishing Company,

Temu Ilmiah Geriatri Semarang. (2008). Perawatan Restoratif untuk Mencegah Gagal Pulih pada Lanjut Usia di Masyarakat. Semarang. Bagian Ilmu Penyakit Dalam FK. UNDIP

Tomey, A.M., dan Alligood, M.R. (2006). Nursing theorists and their work. (sixth ed). St Louis: Mosby Elsevier.

Undang-Undang Republik Indonesia No. 36 Tahun 2009 Tentang Kesehatan

Wallace Meredith. (2008). Essentials of Gerontological Nursing. Springer Publishing Company, LLC

WHO. (2014). World Health Statistics 2014: World Health Organization

WHO. (2013). A Global Brief on Hypertension: Silent Killer Global Public Health Crisis

Wolff, Hanns Peter. (2008). Hipertensi. Jakarta: PT. Bhuana Ilmu Populer, Gramedia

Wong, S. S., Dixon, L. B., Gilbride, J. A., Chin, W. W., \& Kwan, T. W. (2010). Diet, Physical Activity, and Cardiovascular Disease Risk Factors Among Older Chinese Americans Living in New York City. J. Community Health. 36: 446-455.

Yang, X., Zhao, H., Wang, J. (2014). Chinese massage (Tuina) for the treatment of essential hypertension: Asystematic review and meta analysis. Journal Complementary Therapies in Medicine 22, 541-548. Publisher by Elsevier Ltd.

Yogiantoro, M. (2007). Hipertensi Esensial, dalam Sudoyo, A.R. (Eds), Ilmu Penyakit Dalam. (pp. 599 -603). Jakarta: Pusat Penerbit IPD FKUI 